\title{
Article
}

\section{Palm Oil and Crude Oil: Environmental Damage, Resource Conflict, and Literary Strategies in the Niger Delta}

Reddick, Yvonne

Available at http://clok.uclan.ac.uk/21499/

Reddick, Yvonne ORCID: 0000-0002-7869-7560 (2019) Palm Oil and Crude Oil: Environmental Damage, Resource Conflict, and Literary Strategies in the Niger Delta. Interdisciplinary Studies in Literature and Environment, 26 (3). pp. 688-721. ISSN 1076-0962

It is advisable to refer to the publisher's version if you intend to cite from the work. http://dx.doi.org/10.1093/isle//isz061

For more information about UCLan's research in this area go to http://www.uclan.ac.uk/researchgroups/ and search for <name of research Group>.

For information about Research generally at UCLan please go to http://www.uclan.ac.uk/research/

All outputs in CLoK are protected by Intellectual Property Rights law, including Copyright law. Copyright, IPR and Moral Rights for the works on this site are retained by the individual authors and/or other copyright owners. Terms and conditions for use of this material are defined in the policies page. 
$\underline{\text { Palm oil and crude oil: environmental damage, resource conflict and literary }}$

\section{$\underline{\text { strategies in the Niger Delta }}$}

The exploitation of petroleum reserves in Nigeria's Niger Delta by foreign oil companies has been widely condemned as environmentally damaging, and even neo-colonial. Existing ecocritical scholarship on literature from the Delta by scholars such as Nixon (2011) and Caminero-Santangelo (2014) has focused on literature that engages with the extraction of mineral oil. While their analyses of the environmental, economic and social violence that this causes are important, it is disappointing that Wenzel (2006) and Lincoln (2012) are among the few environmentally-engaged literary critics to examine writing about the area's long history of foreign resource exploitation. This article analyses the different literary strategies employed by key prose writers, poets and playwrights, and shows how some engage with the transition from a palm oil economy to a petroleum economy, while others present a pastoral picture of the Niger Delta before oil in order to throw the damage caused by petroleum into relief. Although its impacts were nowhere near as severe as those of petroleum exploitation, the palm oil industry caused water pollution, deforestation, riots and conflict long before mineral oil was struck in Nigeria in 1956. 
Foreign petroleum exploitation has long been a focus of writing from the Niger Delta, notably the work of Tanure Ojaide, Ken Saro-Wiwa, and authors following in their wake. In Nigeria, petroleum is an economic mainstay and 'has saturated virtually every aspect of economy, polity and sociability' (Watts 2009 12). However, mineral oil is not the only contested natural resource that Nigerian authors examine. Existing ecocritical scholarship on literature from the Niger Delta by scholars such as Nixon (2011) and Caminero-Santangelo (2014) has focused on authors who engage with petroleum. While their analyses of the environmental, economic and social problems that this causes are important, it is disappointing that Wenzel (2006) and Lincoln (2012) are among the few environmentally-engaged literary critics to examine literature about the area's long history of resource exploitation before the discovery of petroleum. As historians have often argued, ${ }^{1}$ the palm oil trade had caused environmental and social problems in the Niger Delta during colonial and protectorate times; commodities such as ivory and rubber were also exploited. Although the environmental impact of palm oil cultivation and processing was nowhere near as severe as the destruction created by petroleum, it created conflicts over resources that are remembered in the work of several Nigerian writers. Equally significant is the way that certain authors strategically omit the conflicts and environmental problems created by the palm oil trade: this article contends that this is a strategy to throw into relief the problems brought by petroleum.

\footnotetext{
${ }^{1}$ For further information on conflict caused by the palm oil trade, see E. J. Alagoa, A History of the Niger Delta: An Historical Interpretation of Ijo oral tradition. Ibadan: Ibadan UP, 1972. O. C. Asuk, 'Two Oils, Same Phenomena: Historicizing Exclusion, Poverty and Contemporary Violence in the Niger Delta.' African Research Review 5.2 (April 2011): 1-15. Martin Lynn, Commerce and Economic Change in West Africa: The palm oil trade in the nineteenth century. Cambridge: Cambridge UP, 1997. Obaro Ikime, Niger Delta Rivalry: Itsekiri-Urhobo Relations and the European Presence, 1884-1936. Harlow: Longman, 1970.
} 
This article analyses the literary forms that five Nigerian writers use to document environmental change during the transition from palm oil to mineral oil exploitation. Ben Okri’s short story 'What the Tapster Saw' (1987), which Wenzel has termed an example of 'petro-magic realism', marks the transition from indigenous palm oil cultivation to late colonial mineral oil extraction. This article makes the ecocritical intervention that magical realism enables Okri to put the distinction between human and nonhuman under pressure, and to highlight the seemingly autonomous life of oil. In his manifesto Genocide in Nigeria (1992), Saro-Wiwa is shown to reinvent the testimonial-narrative by affiliating with Western authors such as Gide and Carson; to deploy the rhetoric of political lobbying; and to borrow pastoral and elegiac devices from poetry. Environmental and economic conflicts in the Niger Delta have inspired several generations of poets, and this article examines how Tanure Ojaide and Ogaga Ifowodo borrow devices from epic poetry, political protest-verse, and harness poetry's flexible ability either to develop a plotline or evoke narrative breakdown. J. P. Clark-Bekederemo's 2000 play All for Oil posits the colonial palm oil industry as a forerunner of Nigeria's contemporary petroleum economy, branding both as manifestations of exploitative international capitalism.

Nigeria's 'resource curse' has created severe environmental problems and gross economic inequalities. The United Nations Environmental Programme identifies Ogoniland, in the central part of the southern Delta, as having 'contaminated land, groundwater, surface water, sediment, vegetation, [and] air pollution'. These create public health problems (8) and damage biodiversity. The human cost of economic inequality is 90 million Nigerians survive on under one dollar a day (Nixon 106). 
What is more, resistance to the multinationals has been brutally quashed: 'Chevron, for example, has acknowledged transporting Nigerian forces to quell uprisings in the oil camps of Rivers State. Shell has imported arms for the Nigerian police, paid retainers to Nigerian military personnel, and made boats and helicopters available to them', (Nixon 107). Critic Ogaga Okuyade points out that 'African literature on the environment continues to be engagingly combative, in order to re-order the lopsided ecological geometry of the continent' (2013, xii). The 'combative' tendencies in environmental literature reflect resource conflict on a massive scale. Watts has noted that the Niger Delta's recent oil conflicts occur on multiple levels:

There are a number of insurgent groups like MEND and NDPVF engaged in armed struggle against the state and the oil companies. There are also intercommunity (both inter-ethnic and intra-ethnic) conflicts often driven by land and jurisdictional disputes over oil-bearing lands (and correspondingly over access to cash payments and rents from the oil companies). There is urban interethnic warfare - most dramatically seen in the decade-long battles between Ijaw, Urhobo and Itsekeri communities in Warri over "who owns Warri”. Central to these struggles in which perhaps 700,000 people have been displaced and thousands killed, is the ethnic delineation of electoral wards and local government councils (2009 19).

Amidst these conditions, the petroleum industry has led authors to create new forms of literary protest and expression; this article analyses how and why they do this.

\section{$\underline{\text { Historical resource conflicts }}$}


In wealthier countries, the petroleum economy has created an entire 'regime of living' based on a 'culture of automobility' (Watts 2009 11-12). For some scholars, petroleum has ushered in a new economic phase: 'without oil, current configurations of capital are impossible' (Szeman 817). Palm oil was not as important to the world economy during colonial times as petroleum is currently, but it was part of a rise in commodity production in Africa that Maddox terms a 'commercial revolution': a continuation of the process of globalisation that had begun with slavery (105). Wenzel overstates the case when she writes that 'palm oil was perhaps as indispensable for nineteenth-century industry as petroleum was for twentieth-century industry' - this ignores the previous era's 'coal capitalism' (Frederick Buell 2085). Yet palm oil was indeed a staple commodity for the British Empire, used for everything from soap to industrial lubricant (Wenzel 452).

The Niger Delta has a long history of foreign exploitation - both human and environmental. The British named their Oil Rivers Protectorate for palm oil in 1884, and palm oil produced for export in southern Nigeria was intended primarily for the British market (Maddox 106). Prior to that, the Delta's coastline was known as the 'Slave Coast'. ${ }^{2}$ As Watts writes, 'The petroleum frontier followed the slave and palmoil frontiers of the seventeenth, eighteenth, and nineteenth centuries' (2014 loc. 5320). Palm oil cultivation had long been a source of income for Delta peoples: an indigenous palm oil industry had predated production for the European market and

\footnotetext{
${ }^{2}$ It is curious that so few of the literary works examined here explore the historical trauma of slavery whether trans-African, transatlantic, or domestic. An exception is when Clark-Bekederemo mentions chains carried by the British (34), which cannot fail to evoke the former practices of the slaving era; he also mentions forced labour in colonial Nigeria (29). Noo Saro-Wiwa explains that Nigerians' understated responses to the slave trade are because they are 'not descended from slaves' (56); nevertheless, the transatlantic trade caused depopulation and was supplied by inter-ethnic conflict; slaves were also possessed by Nigerian owners of oil palms.
} 
continued alongside it. Niger Delta people began harvesting oil from semi-wild trees (Martin 1988 11), to supplement their subsistence farming of crops such as yams. The oil palm produces other usable products, from building materials to palm wine (Aghalino 22). Yet the export of palm oil to Europe dates from as early as the 1480s, and was worth a million pounds by 1840 (Wenzel 452). After the abolition of slavery, British merchants perceived the trade in palm oil as an economically viable and ethically 'legitimate' replacement for the slave trade (Lynn 63). However, palm oil production did not increase because of the decline in the slave trade. Palm cultivation was done both on locally-owned estates, using slave labour, and on smallholdings. In both situations, women were responsible for most of the labour (Falola and Heaton 80).

In the Niger Delta, Berger and Martin note that 'oil palms were planted deliberately in swampy regions outside their natural habitat.' However, 'the bulk of production was carried out using natural groves' (398), although by the middle of the nineteenth century, Maddox writes that 'the expansion of palm oil production had led to increased clearing of the forest for palm oil planting' (107). British involvement intensified palm oil cultivation (Aghalino 23-27), but in spite of this, plantation agriculture was not widespread in the Niger Delta. The hero of J. P. ClarkBekederemo's play meets with the Lever brothers (41); Lever requested palm oil concessions in Nigeria in 1907, although his request was not granted (Berger and Martin 398). The only concessionary palm oil company in the Niger Delta was the United Africa Company (Aghalino 25). This meant that the cultivation of oil palms remained largely the preserve of smallholders (Berger and Martin 398). 
Nixon has examined the parallels between recent neoliberal acquisition of resourcerich land in poorer countries, and the concessionary mining and plantation companies that operated during colonial times (120). In spite of this, he does not develop his line of argument to examine the damaging effects of the palm oil trade. He notes that when 'Shell was driven out of Ogoniland in 1993, it simply moved on to other parts of Nigeria's once lush delta of death' (107). The 'delta of death' had been the site of colonial and protectorate-era resource conflicts, which Saro-Wiwa mentions and which Clark-Bekederemo dramatises. The lushness of this region was not due to 'virgin' forest: in some areas, the trees were deliberately cleared to make way for palms. The clearing of forests to make way for agriculture and oil palms had ecological consequences that were visible by the early days of colonial rule: 'as they cleared the primary forest, the sanctuary of the larger animals and [...] wild game began to disappear,' with leopards and elephants extinct in the Ngwa region in the 1920s (Martin 1988 28). Another important environmental problem associated with palm oil processing is the effluent it produces, which pollutes watercourses and decomposes to produce climate change-inducing biogas (Hosseini and Wahid 773-4). The oil-ravaged landscapes that Saro-Wiwa, Okri and Ifowodo evoke in their writing are the scenes of significantly more acute environmental damage; but the environmental impact of the palm oil industry should not be ignored. ClarkBekederemo's play All for Oil and Okri's short story 'What the Tapster Saw', alongside works such as Ola Rotimi’s play Akassa You Mi (1977), examine the long history of resource conflict in the region. As DeLoughrey and Cilano note, 'a vital aspect of postcolonial ecocriticism refuses the nostalgia of pure landscape even while it grapples with the best ways of addressing the representation of the nonhuman 
environment' (79). Okri, Clark-Bekederemo and Rotimi refuse the nostalgia of pure landscape, but Ojaide, Saro-Wiwa and Ifowodo deploy it strategically.

The scale of the resource conflict and environmental devastation that accompanied oil extraction has created some degree of nostalgia for the palm oil economy. ${ }^{3}$ As Wenzel notes:

it is possible that the rise of petroleum makes palm seem more 'local', less alienated and alienating, that petro-violence makes palm seem peaceful by comparison. Andrew Apter argues, in a similar vein, that, 'As a moral economy recalled with nostalgia, the palm-oil trade and the forms of "natural value" that it invoked $[\ldots]$ established a profound contrast with the immoral economy of petroleum, which pumps bad money from beneath the ground, only to pollute and destroy the productive base of the economy. (453)

Nevertheless, the palm oil trade had caused troubles such as the 1895 conflict known as the 'White man's war' between the Royal Niger Company (Green ix), and it played a role in the 'Women's Tax Riots' of 1929 (Saro-Wiwa 16); these conflicts will be examined shortly.

Environmentally-aware writing about oil cultures in the Niger Delta began to develop with authors who lived through the polluting practices of the oil boom, which Tanure Ojaide began to notice in the 1960s (1994 15). Their generation later endured the

\footnotetext{
${ }^{3}$ A photograph by George Osodi emblematises some Nigerian culture products' reluctance to engage with the problems of the international colonial-era palm oil trade - and the contemporary palm oil industry in other parts of West Africa. Osodi's powerful photo essay Delta Nigeria: The Rape of Paradise contains an image of men shovelling oil palm fruit, captioned 'Processing palm fruit to extract the palm oil, an industry abandoned for crude oil' (Osodi 142). The palm oil industry has not been abandoned, but continues, albeit in a reduced form.
} 
devastation of the Biafran War, whose flames were fuelled, in part, by oil conflict. An important writer for ecocritics such as Caminero-Santangelo (2014) and Okuyade (2013), Ojaide's early work offers a good example of the construction of the palm economy as 'local' and 'moral', in comparison with the ravages of petroleum. Ojaide writes that the Delta's 'folklore, fauna, and flora, no doubt enriched my Children of Iroko and Labyrinths of the Delta' (1994 15), his poetry collections of 1973 and 1986; his poetry shifts from a 'celebration of the environment to a lamentation for its demise' with 'the anger of the 1970s and 1980s' (16). His vision of the palm oil industry is of a traditional economy, where he 'followed [his] father and uncles to the palm-oil press,' a 'canoelike structure' (15) that could not be more evocative of the riverine traditions of the Niger Delta. Ojaide presents palm cultivation for local consumption; the region's historic international palm industry is not mentioned. He contrasts the sustainability of local palm cultivation - 'there were specified seasons for cutting palm-nut branches' - with the less traditional practices of clearing forest, fishing with chemicals, and especially the petroleum industry (16). Yet, significantly, Ojaide's protest poem against petroleum exploitation, 'Ughelli,' sets up a metaphorical equivalence between the palm oil industry and the petroleum industry's appropriation of resources: 'for the palm's oil to be called the fig's' (1986 74). The metaphor hints at the region's long history of oil industries, yet the characterisation of 'the palm's oil' as quintessentially autochthonous conceals the social and economic disruption brought by colonial cultivation. Ojaide's subsequent writing about petroleum will be examined alongside that of younger poets later in this article, while the transition from one oil industry to another is taken up in the work of Ben Okri. 
Okri's story 'What the Tapster Saw' (1987) in Stars of the New Curfew (1988) is one of the earliest texts examined here as a record of how the shift from a palm oil economy to a petroleum economy has created conflict and environmental damage. Wenzel has analysed the story as an example of 'petro-magic realism' (450), placing it within the tradition of Amos Tutuola's celebrated novel The Palm-Wine Drinkard (1952):

The palm-wine tapster is an agent of production within a local network of consumption, yet I argue that these fantastic tales situate the tapster on the margins of a broader export economy, whether of palm products, petroleum, or Nigerian literature itself: the palm wine tapsters see, or make visible, the mutual, if uneven, pressures of the global and the local (450).

Tutuola's palm-wine tapster is indeed an agent of production in a local network of palm wine consumption, sourcing palm tree sap to be fermented for his employer the 'drinkard'. But he is definitely not on the 'margins' of a broader export economy: it surrounds him, since he taps the trees of an oil palm farm. Although Wenzel writes that the palm oil export economy must be 'read into the novel' (452), she does not pinpoint the moments in Tutuola's text that indicate it. At the beginning of the novel, Tutuola gives us very specific information about currency; this points to the foundations of the economy in which the tapster and the narrator participate. Tutuola's narrator notes that 'we did not know other money, except COWRIES, so that everything was very cheap' (7). Slaves could be exchanged for cowries; nevertheless, the cowrie shell 'was intimately involved with palm oil broking' and ' $[\mathrm{t}]$ he increasing use of cowries in parts of West Africa in the nineteenth century, particularly after c. 1820 , was closely tied to the growth of the oil trade' (Lynn 70). ${ }^{4}$ The source of the narrator's inherited fortune is palm oil. The trade in this commodity

\footnotetext{
${ }^{4}$ It is significant that from page eighteen onwards, Tutuola's narrator speaks of currency in terms of pounds sterling: cowries are replaced by the colonial currency.
} 
on both international and local scales provides the economic backdrop for this important Nigerian novel, and for authors who follow in Tutuola's wake.

Okri's magical realism is frequently affiliated with Tutuola's Yoruba tales (Warnes 126-7, James 2012 274). Earlier critical analyses of Okri's short story have largely focused on the economic conditions that have prompted his use of magical realism. For Lincoln, 'the supplanting of an economy based on palm oil by one based on petroleum extraction is a trauma that finds expression in the peculiarly hybrid and unsettled form of 'What the Tapster Saw' (103). Wenzel rightly calls this 'petromagic-realism, a literary mode that combines the transmogrifying creatures and liminal space of the forest in Yoruba narrative tradition with the monstrous-butmundane violence of oil exploration and extraction, the state violence that supports it, and the environmental degradation that it causes.' (456). According to Lincoln, Okri's book depicts 'Nigerian society being transformed by the excess of petrodollars flooding the country during the 1970s oil boom' (252), although the collection as a whole was written during the worst of the 1980s' slump in oil prices (250). Okri's work clearly examines these important considerations, but his use of magical realism to convey environmental concerns needs to be subjected to closer critical scrutiny.

If we take Warnes's basic definition of magical realism, it is 'a mode of narration that naturalises or normalises the supernatural; that is to say, a mode in which real and fantastic, natural and supernatural, are coherently represented in a state of equivalence' (3). Magical realism, for Warnes, is often shown to 'deconstruct notions of subjectivity, history, nationhood, reality', but it is important to emphasise how it 'can also construct these notions' (7). In Okri's text, what is deconstructed is clearly a 
sense of reality and the challenges of Nigerian nationhood; he constructs alternative histories and an enhanced subjectivity for the tapster. But crucially for this ecocritical analysis of Okri, he also deconstructs the perceived boundary between human beings and their wider environment. What he constructs through his use of magical realism is a sense of the tapster's imbrication in a wider network of ecological interconnections; human complicity in their disruption; and the importance of oil as a commodity seemingly with an agency of its own.

When Okri quotes a Yoruba myth where an antelope transforms into a woman (loc. 2168), one is alerted to his redeployment of Yoruba narratives to put the boundary between human beings, animals and inanimate things under pressure. Sanchez and Simal have analysed the environmental implications of metamorphosis in magical realist texts from Latin America. They note that the 'extended realism' of magical realism can 'question and deconstruct assumed, normative conventions such as "human versus nonhuman," "nature versus culture"” (197) via human-animal metamorphoses. Giving animate characteristics to inanimate features of the landscape (198), and the 'animalization' of humans (212), suggest an ethics of ecological interrelation (207). Sanchez and Simal's perception of the 'insidious collusion of the war machine with global capitalism and environmental crisis' (213) is instructive for Okri's vision of a resource war with disastrous human and environmental consequences.

Okri uses the device of prolepsis, allowing the tapster (presumably just after oil has been struck, in 1956) to see the future. He deploys magical realism to allow the tapster to experience both the full extent of the damage done by the 'Delta Oil 
Company' - and one of the first indicators of this during his hallucination is the clearing of reduction of a new palm grove to 'earth-mounds, gravestones, a single palm tree, and flickering mangrove roots'. Here is the first mention of human casualties; but linked to their deaths is the destruction of the environment, emblematised by the mangrove roots that nurture aquatic life, and the destruction of the palm oil and palm wine economy, emblematised by that lone tree. During the 1970s oil boom, Nigeria even began to import palm oil (Falola and Heaton 182). A mark on the surviving palm tree becomes a 'fully festered wound' that troubles the mangrove roots (Okri loc. 2189): this frames the palm as a 'natural' agricultural staple of the Niger Delta, enmeshed within the mangrove ecosystem. Okri's presentation of palm cultivation as 'natural' is strategic, but it serves to highlight the greater environmental cost of the petroleum economy. Lincoln has argued that 'The wounded, bleeding trees that entrap and torture [the tapster], and his rape by a creature whose only characteristic is its stench of "rotting agapanthus," serve as vivid examples of a device that frequently appears in Okri's work, wherein sensory characteristics, like colour or smell, and metaphorical figures, like these wounded trees, assume a life of their own and address the human subject directly' (Lincoln 255). What needs to be added to Lincoln's analysis is Okri's radical reappraisal of the relationships between humans and nonhumans here. Trees that take on the characteristics of wounded human flesh create a clear meshing of human and environmental concerns: an emblem for Nixon's influential concept of the 'slow violence' of environmental destruction. Okri will later emphasise the 'bloodiness' of clearing a forest to make way for an expressway in The Famished Road (ctd in James 2012 271); 'in humanizing the trees Okri makes clear both the brutality of environmental degradation and its link to forced migration' (James 272). Delta Oil 
Company's efforts 'to level the forests' (Okri loc 2211) and 'unsuccessful attempts to level the forest area and drill for oil' (2233) are stressed repeatedly. Moreover, Okri's foreshadowing of an economy where petroleum has become all-pervasive engenders another form of personification: oil having a life of its own, emblematised by the talking snake that lives in the depths of the borehole (2232). Here, magical realism enables Okri to show mineral oil ‘exercising its material agency’ (Stoeckl loc. 153) as the dominant product of Nigeria's postcolonial economy. It is such ecological preoccupations that magical realism brings into clearer focus, and which Okri will develop even further as the narrative progresses.

A bizarre episode where the Tapster is raped by a creature whose only characteristic is its smell, highlights how Okri uses magical realism not only to merge human and nonhuman, but to examine the interrelations of environmental violence, petroviolence, and complicity: '[L]ater at night another creature, which smelt of rotting agapanthus, crept above him, copulated with him, and left him the grotesque eggs of their nights together.' The eggs, 'grating' and 'clanking', represent the imminent 'horrible birth' of mechanised oil extraction and petro-capitalism (2211), but they are freighted with additional symbolic value. Here, Okri confounds the vocabulary of mechanisation ('clanking') with the organic ('rotting agapanthus'). Further blurring the tropes of military, organic and petro-industrial, agapanthus later grows around a site where the forest has been cleared with dynamite, 'like blood on a battlefield' (2233). The eggs are linked to war by the image of 'Bombs which had not detonated for freak reasons' (2211); Okri completes the conceit when the eggs do not hatch, but instead explode (2301). This deconstructs and utterly confounds traditional categories of the natural and the artificial, and enables Okri to propose an intrinsic link between 
petroleum and resource conflict. What Okri constructs here is a sense that Niger Delta people are violated by the oil industry (the rape) and left with an aftermath that will affect future generations (the eggs). Yet they are also complicit in inter-ethnic conflict over oil (the tapster himself siring the bomb-like eggs). They give birth to their own petro-modernity.

Also evident is a sense of continuing resource conflict: 'His eyes itched again and he saw that the wars were not yet over [...] And some of those who lived as if the original war was over were blown up while they struggled with poverty' (2211). Unexploded ordnance, coups and armed robberies (2233) encapsulate the conflicts that plagued Nigeria after independence and plunged it into civil war. 1966 saw a succession of coups, first by the 'five majors' (Falola and Heaton 172), then John Aguiyi-Ironsi and finally Yakubu Gowon (174). The 'wars' in Okri's text primarily recall the Biafran War of 1967-1970, provoked by the attempted secession of Biafra an area dominated by the Igbo ethnic majority. Biafra contained $67 \%$ of the country's known oil reserves (Falola and Heaton 175). Biafrans viewed the war as the 'genocide' of the Igbo people (175), a term that eerily prefigures Saro-Wiwa's later accusation. However, Okri's ambiguous term - 'the original war' - opens the possibility of interpreting this as a multitude of 'original' wars from imperialist domination onwards.

The turbulent temporal structure of Okri's fiction - the premonitive dream, the proleptic picture of future warfare, flashbacks and the framing device of the tapster's coma - mirrors the fragmented history of a region subjected to postcolonial civil war and 'recolonization' by foreign oil companies. His radical confounding of categories 
and fragmented plotline reflects the tapster's 'inability to integrate [the exploitation of petroleum] into any narrative he can recognize' (Clark 105). However, it is more redolent still of the massive extent to which human beings have altered our environment in the human-dominated geological era that is the Anthropocene, which some see as most importantly instantiated by climate change linked to our consumption of fuels such as oil (Chakrabarty 2009 210). As Clark summarises it, 'The notion of nature as the other to culture has been giving way in environmental thought to more blended conceptions of the two as forming one perhaps bafflingly complex entity', merged together in the 'inextricable mess' of our human-dominated era (Clark 56-7). While an important goal of the text is clearly to give a proleptic account of economic change, Okri's narrative of transformation is also redolent of the 'inextricable mess' of human and nonhuman impacts in what Saro-Wiwa would later call a 'deadly ecological war' (1995 131).

\section{$\underline{\text { Ken Saro-Wiwa: Polemic, Testimony and Environmental Elegy }}$}

After the oil boom described in Okri's collection of short stories, falling oil prices plunged Nigeria into a recession that lasted from 1981 to 1992 (Falola and Heaton 202). It was towards the end of this recession that Ken Saro-Wiwa published Genocide in Nigeria (1992), his account of violence, neo-colonial behaviour and environmental degradation in the oil-rich Delta. The period of 1983-1999 was marked by the military regimes of Buhari, Babadinga and then Abacha (Falola and Heaton 208). Although these rulers were quick to suppress criticism, their rule stimulated 'the growth of grassroots political activism' (Falola and Heaton 201). In 1989, Saro-Wiwa was elected President of the Ogoni Central Union, organising seminars on Ogoni life, including the environmental degradation that they had suffered since 1970 . He created 
the Movement for the Survival of the Ogoni People (Doron and Falola loc. 1035) and travelled to Geneva in 1992 to participate in the UN Working Group on Indigenous People (1148). Genocide in Nigeria aimed to mobilise more Ogoni, to establish MOSOP's nonviolent credentials, and to link 'environmental calamity to the political and economic marginalization that the Ogoni suffered' (1157). The book developed from Saro-Wiwa's human rights advocacy and environmental campaigns. Of course, Saro-Wiwa would eventually pay the ultimate price for his activism.

Ken Saro-Wiwa's work deploys several devices associated with oil culture: an 'exuberance' similar to writing about the early oil industry in the USA, closely wedded to the 'catastrophe' of blowouts, then toxic pollution described by Carson and finally climate change (Frederick Buell loc. 2416-20). Saro-Wiwa certainly deploys the rhetoric of catastrophe, but an important element of his manifesto-memoir is also testimony. Writing about literature's engagement with oil both the Gulf of Mexico and the Niger Delta, LeMenager argues that testimony is invariably personal:

Living in oil, through injury and pleasure, is personal, not easily transmissible as story. [...] As Jacques Derrida argues, testimony and poetry are alike in their resistance to translation. What we do with testimony is enter into a contract with it, taking it on faith rather than as information that might be conveyed for itself, apart from the presence of the witness. (LeMenager 17).

What Saro-Wiwa does with his testimonial, however, is to create a 'deeply international sensibility' (Nixon 109). Part of his literary strategy for going beyond the personal, untranslatable aspects of testimonial is his deployment of diverse genres and a cosmopolitan perspective. 
Saro-Wiwa sets out his cause, then moves to a chronological account of colonialism, the Biafran war and Shell-BP's 'recolonization', and ends with a bill of rights. Although its narrative arc is logical, the book borrows from a heterogeneous patchwork of genres. It combines an arsenal of techniques from history and manifesto, reportage and rhetoric. Rachel Carson's Silent Spring inspires a passage of elegiac environmental jeremiad, and some surprising devices are borrowed from medieval European poetry. Saro-Wiwa's last book A Month and a Day contains elements of 'diary, memoir, journal, manifesto, advocacy journalism, ethnography, and satire, throwing in for good measure some transcribed speeches and a bill of rights', a hybrid text whose form echoes 'the propulsive urgency of colliding forms as Saro-Wiwa strives to fit into a single book an ill-fitting set of causes by binding together, in unprecedented ways, an African commitment to environmental and human rights' (Nixon 123). The formal heterogeneity of Genocide in Nigeria also bears witness to a period of unprecedented economic and environmental change: the Ogoni had the misfortune to live on the territory from which nearly half of the oil in Nigeria was extracted at the time (Falola and Heaton 231). Nixon points out that SaroWiwa's manifesto has parallels in African political writing by authors such as Ngugi wa Thiong'o and Mafika Gwala, but Saro-Wiwa innovates because he is 'the first African writer to articulate the literature of commitment in expressly environmental terms' (Nixon 109). Saro-Wiwa affiliates Genocide in Nigeria explicitly with Gide's Voyage au Congo (1927), a text that describes 'the gross abuse of human rights' by King Leopold II's regime, with the result that 'Europeans were sufficiently shocked to end the abuses' (Saro-Wiwa 1992 9). Surprisingly, however, Nixon does not draw parallels between Genocide in Nigeria and Silent Spring, although he points out similarities between Wangari Maathai and Rachel Carson as women 
environmentalists (144-48). Yet Saro-Wiwa's work certainly draws some features from Carson’s influential exposé of ‘occult toxic networks’ (Buell 1998 648), showing pointedly that Buell's idea of 'toxic discourse' is by no means confined to regions ‘influenced by Western environmental institutions' (639), but is applicable also to areas whose environments the West has ravaged.

It is Carson whose work inspires Saro-Wiwa's evocation of an environmentally conscious population in harmony with its paradisal surroundings. Here is a section from the first chapter of Genocide in Nigeria, juxtaposed with Carson's 'A Fable for Tomorrow':

Ogoni was always a blessed land. The plateau soil was extremely rich, the fresh water streams and the surrounding seas brimmed with fish, the forests had an abundance of animals and hard woods preserved by the environment-conscious Ogoni (my father was a forest-ranger) and the Ogoni were extremely hardworking. We were very well fed and the Ogoni people lacked for nothing (Saro-Wiwa 1992 18).

\footnotetext{
${ }^{5}$ Toxic discourse, for Buell, springs from 'an anxiously industrializing culture' (639) - not unlike the rapidly petro-industrialised Niger Delta. Buell argues that toxic discourse is employed by environmental justice activists (643) and that poorer and minority communities employ it because they are more likely to be affected by toxic poisoning (642-3) - an idea that Nixon would expand to poorer countries in Slow Violence and the Environmentalism of the Poor (2011). Among its characteristics are 'The spectacle of communities, population groups, and finally the whole earth contaminated by occult toxic networks' (1998 648), the 'threat of infringement' (652), and either invoking 'a sense of place to call a localized collectivity into being' or raising it 'to a higher degree of self-consciousness' (2008 653). Saro-Wiwa does not show that the entire world is contaminated by toxic networks, but rather that western consumers as well as Nigerian elites are complicit in poisoning the Ogoni (8); while he writes of toxic (and foreign) infringement, the main occult networks in his book are the flow of oil money.
} 
There was once a town in the heart of America where all life seemed to live in harmony with its surroundings. The town lay in the midst of a checkerboard of prosperous farms, with fields of grain and hillsides of orchards where, in spring, white clouds of bloom drifted above green fields. [...] The countryside was, in fact, famous for the abundance and variety of its bird life [...] Others came to fish the streams, which flowed clear and cold out of the hills and contained shady pools where trout lay. So it had been from the days many years ago when the first settlers raised their houses, sank their wells, and built their barns. (Carson 21)

Carson's evocation of 'harmony', of 'prosperous farms' inspires Saro-Wiwa's 'rich' soil, while Carson's 'abundant' bird life is echoed by Saro-Wiwa's 'abundance of animals.' The economy of Carson's American town - traced back to the first settlers suggests a premodern utopia, free from the capitalist drive for high agricultural yields that has led to 'over-production' (Carson 26, original emphasis). Saro-Wiwa instead stresses both the importance of agricultural toil and modern educational, religious and medical establishments - set up by the Ogoni themselves (1992 18). The vision he presents is of an unsullied environment that does not exist in a premodern paradise, but instead became highly developed with little foreign input. Saro-Wiwa's use of Edenic imagery to describe the time before mineral oil also follows in the wake of Ojaide's early poetry, which praises the 'virgin beauty of the Delta' and characterises it as 'a tropical garden,' 'proffering bounties' of 'green foliage' (1986 24-25). However, Saro-Wiwa's syncretic allusions to Carson take the book beyond the realm of local or personal testimonial, and help western audiences to identify it as an environmental polemic written on behalf of a people. The success of Carson's Silent 
Spring in changing attitudes among the public and politicians ${ }^{6}$ sets a precedent for Saro-Wiwa's manifesto for environmental justice.

The following excerpt from Saro-Wiwa's 'Author's Note' to his book has the impassioned tone of African political speeches and manifestos - and employs a rich array of rhetorical strategies. 'But because the Nigerian elite appear, on this particular matter, to have hearts of stone and the brains of millipedes; because Shell is a multinational company with the ability to crush whomever it wishes; because the petroleum resources of the Ogoni serve everyone's greed, all the doors seem closed.' (7) This sentence owes its rhetorical verve to a wealth of devices: anaphora, tricolon, irony, metaphor. Anaphora - Saro-Wiwa's repetition of 'because' at the beginning of successive clauses - gives this passage the momentum of political discourse, and echoes freedom-fighters' rhetoric, such as Mandela's 'I am prepared to die' speech: 'There had been violence in $1957 \ldots$; there was violence in $1958 \ldots$..; there was violence in 1959' (Mandela n.p.). The three main clauses that make up the sentence quoted above constitute a tricolon (Lanham 154). The device of using three clauses is aesthetically pleasing, but here, Saro-Wiwa draws on its use in emancipatory movements, such as Mandela's 'Manifesto of Umkhonto': ‘in defence of our people, our future, and our freedom' (Mandela n.p.) Irony - 'the brains of millipedes' sharpens the sting of Saro-Wiwa's criticism. The sentence is both the movement's rallying-cry and a bitterly ironic indictment of the status quo. It has the effect of augmenting the testimonial narrative with the collective weight of a political

\footnotetext{
${ }^{6}$ The book created a widespread change in attitudes and caused Kennedy to commission a report on pesticides (Rome 532).
} 
movement, taking this oil-narrative beyond the local and presenting it to an international audience.

Although he deploys the rhetoric of speechmaking and manifestos, some of the most lyrical moments in his book draws devices from poetry and from Carson:

I hear the plaintive cry of the Ogoni plains mourning the birds that no longer sing at dawn; I hear the dirge for trees whose branches wither in the blaze of gas flares, whose roots lie in infertile graves. The brimming streams gurgle no more, their harvest floats on waters poisoned by oil spillages.

Where are the antelopes, the squirrels, the sacred tortoises, the snails, the lions and tigers which roamed this land? Where are the crabs, periwinkles, mudskippers, cockles, shrimps and all which found sanctuary in mudbanks, under the protective roots of mangrove trees?

I hear in my heart the howls of death in the polluted air of my beloved homeland; I sing a dirge for my children, my compatriots and their progeny. (1992 83)

One cannot but think of Carson when one reads of the Ogoniland birds' ceasing to sing. The hyperbole of 'howls of death' belongs to the 'moral melodrama' and 'totalizing rhetoric' (Buell 1998 659) that characterises toxic discourse. Yet SaroWiwa is not only drawing on her environmental jeremiad here - he takes inspiration from poetry. He begins this passage with personification, a trope associated with poetry as well as rhetoric, lending a voice to the voiceless Ogoni plains. This is a device deployed in Ojaide's poem 'Ughelli', which envisages the town as a woman 
who is 'dry-skinned when her oil rejuvenates hags' (1986 74). Personification has been criticised by some ecopoetics scholars as an anthropocentric device, termed 'colonizing' by Gilcrest (53). However, Knickerbocker sees personification as an acknowledgment that 'the nonhuman world takes note of us', transforming the nonhuman into an 'interlocutor' (6). Here, it also functions to frame Saro-Wiwa as deeply connected to his environment, in a way that no foreign oil prospector can be. Saro-Wiwa evokes the musical and poetic forms of the 'lament' and the 'dirge', but a further formal device is borrowed from poetry - and medieval European poetry at that. When he asks 'Where are...?' he echoes the medieval 'Ubi sunt ...?, or 'where are they?', an elegiac mode evoking 'the transitoriness of life or beauty' $(O E D)$. This syncretic blend of literary devices helps Saro-Wiwa to broaden his testimonialnarrative out for a wider readership, but the rhetorical questions also confront the reader directly: a reminder to his European and North American readers that they benefit from Nigerian, oil, that 'it is Western investment and technology which keep the Nigerian oil industry and therefore the Nigerian nation alive' (8), and that they are complicit in the despoliation of these landscapes.

Yet the most important mode in this passage from Genocide in Nigeria is elegy. This is usually 'a song or poem of lamentation, especially for the dead' $(O E D)$; an aptly sombre mode given that Saro-Wiwa's argument that the oil companies' combination of environmental and physical violence is 'genocide' (83). However, the suffering of the people is concomitant with the suffering of their land in this sentence. Saro-Wiwa draws on Nigerian poetic laments that use nature-imagery to carry a powerful political charge, such as Ojaide's 'Death of the Warrior', which envisages the assassinated military ruler Murtala Mohammed as the felled 'pride of the forest' (1986 40). Yet in 
the passages from Genocide in Nigeria quoted above, Saro-Wiwa is writing in a particular sub-genre of elegy: the environmental elegy. While traditional British elegies, such as Milton's 'Lycidas', enable the bereaved to find consolation in 'the rebirth of the dead in nature' (Ramazani 4), environmental elegies are incapable of reaching such resolution because the process of environmental destruction remains ongoing. Timothy Morton finds that the elegiac work of mourning for a damaged environment can never fully be accomplished because we 'have lost the objective correlative for loss itself' (2010 253-54). Environmental elegy necessarily has a forward-looking dimension: it ponders problems that will continue in the future (Morton 2010 254; Gilcrest 22). This is certainly the case in Saro-Wiwa's work: his lament is for 'my children' and the 'progeny' of his compatriots as well as for his generation. Prospective laments, in the form of the proleptic devices of prophecies and visions, are also used by Okri and Clark-Bekederemo to decry events that have not fully taken hold in the timeframe of the narrative. The elegiac mode here succeeds in balancing personal testimonial with collective lament: the 'home-land' is both Ogoni and any damaged region of Nigeria, while the 'compatriots' could be any Nigerian community oppressed by the ethnic majority.

Saro-Wiwa's descriptions of a pre-petroleum Niger Delta, alongside certain poems by Ojaide and Ifowodo, can be seen as creating a postcolonial version of the pastoral. Saro-Wiwa's work is also an important touchstone for later writers who employ the pastoral. Buell writes of American authors who use the pastoral as a foil for toxic discourse: 'it makes sense for toxic discourse to enlist pastoral support. It inverts and democratizes the pastoral ideal: a nurturing space of clean air, clean water, and pleasant uncluttered surroundings that is ours by right' (1998 648). In his analysis of 
the pastoral in Western literature, Terry Gifford defines the pastoral as 'an idealised text [that] often emphasises fertility, resilience, beauty and unthreatened stability in nature. These are complacent and comforting representations of nature that strategically omit any sense of elements that might be counter to this positive image' (2012 8.) If Saro-Wiwa and writers who continue his legacy create pastoral images of Nigeria before oil, they do so as a strategy to argue that a clean landscape is 'ours by right' and to mobilise support for their cause.

In a postcolonial context, the pastoral takes on particular connotations. Lawence Buell terms this the 'indigene pastoral': 'a traditional, holistic, nonmetropolitan, natureattuned myth of Africanity in reaction to and critique of a more urbanized, "artificial" European order' (1995 64). 'Indigene pastoral' is, of course, problematic and open to criticism: Nuruddin Farah's Secrets satirises appeals to 'authoritative secrets of nature' (Caminero-Santangelo 37). African societies often lived more sustainably before industrialisation than afterwards - but it is important not to assume that this was invariably the case. Citing the example of the decline of Greater Zimbabwe in the fifteenth century, William Beinart argues that precolonial African practices were not always in harmony with local ecologies (288). In the work of Saro-Wiwa and other environmentally-engaged Niger Delta writers, the 'indigene pastoral' can be termed a 'pre-petroleum pastoral'. However, there are important hints in Saro-Wiwa's text that the Ogoni were involved in the international palm oil economy that preceded the oil industry, and in agriculture that supported the slave trade; these economic activities brought some benefit, but came with their costs. 
Saro-Wiwa presents the Ogoni as largely unaffected by slavery (14) and distant from 'the nearest anchorages of the European trading ships' (15) - palm oil was among the commodities that those ships traded. Nevertheless, he notes that Ogoni women joined in the Women's Tax Riots (16), which was a response to the threat that their earnings - largely from palm oil production - would be taxed. ${ }^{7}$ However, this particular region had already experienced significant environmental change due to human actions: from the early twentieth century, it was intensively cultivated. The Ogoni had even produced food that was taken on board slave ships. Until the end of the nineteenth century, Ogoniland was densely forested. With population growth and an increased demand for produce from the Delta, the early twentieth century witnessed widespread deforestation to make way for farmland. A growing population meant that even the wetter regions were cultivated for cassava, endangering valuable water resources and impoverishing the soils (Kpone-Tonwe and Salmons 275). Thus, the Ogoni did not live in a 'pure' environment untouched by foreign influence, and they did overcultivate their land. The environmental damage that this created was nowhere near as destructive or extensive as that wreaked by oil exploitation. But the environmental history of the area shows that Saro-Wiwa's use of the 'pre-petroleum pastoral' is a strategic device to persuade the Ogoni to mobilise for environmental reparation.

\footnotetext{
${ }^{7}$ Saro-Wiwa using the colonial term 'riots', rather than the term 'women's war', which was employed by the 10,000 largely Igbo and Ibibio-speaking women who took part (Matera, Bastian and Kingsley Kent 1-2). Palm oil was a primary product of their economic activity (3). The 'war' was in part a response to new colonial measures that led to a reduction in the price fetched by their palm oil (140). In a significant echo of the area's history of oil exploitation, women deployed one particular tactic of the 'Women's War' - threatening to shame the men by going naked in public - against ChevronTexaco in 2002 , to demand better infrastructure and an improvement in environmental conditions (1).
} 
In the face of continued pollution and outbreaks of violence, and with ethnic minorities other than the Ogoni demanding environmental justice and control over oil, Nigerian environmental writing has developed into an important literary movement. Environmental literature from the Niger Delta includes poetry, novels and lifewriting. Novelist Helon Habila's Oil on Water (2010) combines the narrative of a kidnapping with a post-Conradian journey up a polluted Niger River. There are environmental elements in Nnedi Okrafor's science fiction novel Lagoon (2014), which begins with a swordfish sabotaging an oil pipeline. Noo Saro-Wiwa's travelmemoir Looking for Transwonderland: Travels in Nigeria (2013) features visits to nature reserves. Sule Emmanuel Egya interprets poets Gabriel Okara, Christian Otobotekere, Tanure Ojaide, Ogaga Ifowodo, Nnimmo Bassey and Ebi Yeibo as ecopoets of the Niger Delta (2016). Tanure Ojaide's Delta Blues (1998), and Ogaga Ifowodo's The Oil Lamp (2005) remember Ken Saro-Wiwa's legacy, while problematising his ethnocentric thought with important national and diasporan perspectives. For Egya, 'poetry becomes a powerful instrument for conveying resistance; it historicizes the condition of the peoples and their lands, and by doing so raises a counter-narrative in confrontation against powerful institutions, governmental and otherwise, on behalf of the poor people and their environment' (11). There is no doubt that the poets examined here harness the political protest-poem as a genre strategy, and Ojaide has written eloquently of 'the artist's activist role' (1994 17). However, there are important differences between the ways in which Ifowodo and Ojaide's poetry operates in the wake of Saro-Wiwa's death, notably in their use of plot or plot breakdown, formal unity or disintegration. Among earlier critics, LeMenager has commented on Niger Delta writers' use of genre to draw out the predicaments of the 'resource curse' of oil. While her analysis of Ifowodo's use of 
plot is important, her account of the similarities between poetry and the novel are strangely generalising:

[Ifowodo] uses the resonance of poetic language to evoke human pain from within a narrative context that includes the political and physical infrastructures of petroleum. Ifowodo's poetry has a strong narrative element, and in terms of genre we might see him meeting [Helon] Habila halfway — from the narrative poem to the lyric novel, associative logics generating emotional knowledge in and around the interpretive effort of plot. (LeMenager129).

She later makes the unusual statement that 'If what a novel produces is a set of lingering sensations tied to the reader's everyday memory through improvised situational analogies, perhaps it can be called a poem, too' (LeMenager 130). What needs to be added to her arguments is a fuller account of how plot functions in contemporary poetry, and how Nigerian poets employ or refuse it. In Ifowodo's The Oil Lamp, and in Ojaide's mid-career collection Delta Blues, which are analysed here, the breakdown of familiar narratives and the fragmentation of poetic forms are as important as narrative trajectories. Secondly, there is a need for a more nuanced consideration of the possibilities of genre for evoking scale. Habila's novel has been criticised for focusing too closely on the personal feelings of the main character (LeMenager 130). Ojaide's 1998 book ranges between the intensely personal focus of the individual elegy, a broader and more allusive mode that ties him to the community of Nigerian authors, and a political tone that enables him to speak out for a multitude of oppressed groups. Ifowodo's reinvention of the epic genre, however, enables him to create a more wide-ranging view of Niger Delta societies through time. 
Most of Ojaide's poetry collection Delta Blues \& Home Songs (1998) was written in the aftermath of Ken Saro-Wiwa's death, and is dedicated to his memory (Ojaide 1998 9). Poems such as 'Immortal Grief' (20), 'Delta Blues' (21-23) and 'Sleeping in a makeshift grave' (24) were written less than two months after Saro-Wiwa's assassination on the $10^{\text {th }}$ of November 1995 . The collection was published during the last year of Abacha's military rule, and deploys devices such as allegory and metaphor to express vitriolic criticisms of the 'butcher of Abuja' (26), also figured as the mythical tyrant Ogiso (29). Such allusive devices kept the author's head (just) below the parapet, during a regime that had proven highly dangerous to authors. Political allegory is one of the genres that Ojaide draws upon here, as he had in earlier poems such as 'To the Bull' from Labyrinths of the Delta. His formal choices are also underpinned by songs of protest and lamentation, both African American and Nigerian. It is these collective devices that broaden the scope of the collection and invite interpretations by international readers. Yet the prevailing mode of the collection is elegy, for human and environmental subjects. This clashing together of genres suggests that the 'recolonization' of the Delta by oil companies and one of Nigeria's 'most vilified' dictators (Falola and Heaton 228) requires new poetic modes of expression.

In his prose as well as his poetry, Ojaide evokes the despoliation of a lush, green region, although he is from Okpara rather than Ogoni. He argues that it had begun to be spoiled by oil companies even before Saro-Wiwa brought its plight to the attention of the international community: 
The Delta has a special appeal to me ... the vegetation, the evergreen, the heavy rains almost all year round but you know this has been complicated by the coming of the oil companies. I knew when they came. I was only a boy then but I knew. There has been a great change in the environment since they came... long before Ken Saro-Wiwa started to talk about the Delta, as far back as 1973, I was already talking about Ughelli and the other areas; about how they are producing so much and getting little back. Now the environment is destroyed (qtd in Bodunde 196).

Ojaide returns to his earlier theme of the landscape before oil, also echoing SaroWiwa's pre-petroleum pastoral, in the poem 'When green was the lingua franca'. The poem has a personal focus, deploying the lyric I, presenting the speaker's boyhood memories, and using local names for animals and plants - a device that speaks for the Urhobo but risks excluding a foreign reader. Yet the evocation of a 'lingua franca' and an 'alliance' (uniting Delta peoples as well as ecosystems) creates an important collective dimension:

In the forest green was

the lingua franca

with many dialects.

Everybody's favourite, water sparkled $[\ldots]$

Snails and koto lured me to tear through tangles 
that seasoned my soles

to defy every distance.

Urhurhu grapes coloured

my tongue scarlet,

the owe apple fell to me

as cherries and breadfruit

on wind-blessed days [...]

Ikere froglets fell from skies

that covered the land

with tropical sheets;

the skipper-fish overflew

culverts into fisher's ambush.

Undergrowth kept as much

alive as overgrowth, the delta

alliance of big and small,

market of needs, arena

of compensation for all ...

Then Shell broke the bond

with quakes and a hell

of flares. (12-13) 
If Ojaide had focused on 'foliage' and mythical creatures such as 'mermaids' (1986 25) in his earlier poem about the Delta's former beauty, here we see purling streams, shellfish, green mangrove trees and mudskippers. These are the very landscape features and living creatures that Saro-Wiwa had elegised. Ojaide's evocation of a 'market of needs' provides an ecological counterweight to the oil companies' drive for capitalist gain.

Ojaide also draws on the pastoral genre to lament damaged agriculture and felled forests in 'Delta Blues' - but, significantly, he employs personification to speak for a more collective identity. Equally interesting is his evocation of the former palm oil economy. The advent of petroleum is responsible for ruining a harvest of 'palm oil, yams and garri' (21). As in the poem 'Ughelli,' this is a strategic representation. Grouping the crop alongside yams and giving cassava its local name ('garri'), Ojaide stresses the use of palm oil for local trade; significantly, he does not mention its former role in the Oil Rivers Protectorate or its continued exploitation in developing countries. As with Okri's fiction, trees function on multiple symbolic levels:

And for fear of being counted in the register of mad ones, I failed to plant trees beyond my fenced compound in the desert-advancing land. For fear of others' rights, I left the majority to be massacred, a treeful carnage. (14). 
Ojaide's poem is a multi-layered lament for petro-violence. Deforestation is linked to human murder, the 'massacre' of trees recalling Saro-Wiwa's accusations of genocide. The speaker of the poem is frank about his sense of personal guilt, but 'the majority' points to a wronged collective. The advance of the desert suggests localised environmental despoliation, but it is also a reminder that climate change due to the burning of fossil fuels brings the Sahara ever closer. In this respect, Ojaide's poem conforms to Morton and Gilcrest's view that environmental elegy describes an ongoing and irresolvable process of destruction.

Poems such as 'Wails', 'Immortal grief', 'Delta blues' and 'Elegy for nine warriors' announce their status as elegies in their titles; they vary from the long, compressed, breathless column of 'Immortal grief' to the sectioned-off stanzas of 'Wails' and 'Delta blues'. The use of stanzas brings Ojaide's poetry closer to song-lyrics; this is especially significant for the songlike refrains of 'My drum beats itself' and the modelling of 'Wails' on udje dance-songs. The poems written as single columns of text suggest prolonged cries of grief, and the breakdown of the formal poetic devices with the breakdown of traditional ways of life. Ojaide also syncretises Nigerian forms with western ones. Ojaide's title transfers the famous blues of the Mississippi Delta the blues being the archetypal musical lament for African Americans - to the Niger Delta. Five stanzas employ the lyric I, that archetypal mode of expression for European elegists and African American blues singers, but the sixth sees a shift: 'My birds take flight to the sea [...] / The sky singes my evergreen leaves' (22). It is unclear whether a human landowner from the Delta is speaking here, or whether this represents the voice of the Delta itself. For Bate, 'The ecocritical project always involves speaking for its subject rather than speaking as its subject' (72); however, 
the possibility that Ojaide's poem is speaking as the Delta here, echoes Okri's radical blurring of the boundaries between human and nonhuman. It is also a device that opens the poem to interpretation as a collective lament for the Delta's disenfranchised people and damaged environments. Ojaide's book oscillates between the personal and the political, with dedications ranging from personal laments for his friend Ezekiel Okpan, to elegies for Saro-Wiwa and the Ogoni Eight, to poems for fellow writers such as J. P. Clark-Bekederemo, and also the NADECO activists instrumental in toppling Abacha's dictatorship. The juxtaposition of poems broken into regular stanzas, longer pieces with numbered sections, and single columns of free verse, suggests that a fragmented mode is most appropriate for writing about the trauma of widespread petro-violence. There is no sense of an overarching plot, but the poems are instead arranged in almost chronological order by composition date. Even if the dominant structural device in this double poetry collection is fragmentation, 'Serenading the republic' and 'Witness the fire: three pieces' at the end of Home Songs give a sense of resilient defiance.

The younger poet Ogaga Ifowodo's collection The Oil Lamp (2005) deploys a similar versatility of form, but unlike Ojaide, most of Ifowodo's book is a postmodern reworking of the epic. The social and environmental conflict engendered by petroviolence prompts Ifowodo to draw on an array of genres as broad as that deployed by Saro-Wiwa in Genocide in Nigeria. Heterogeneous and allusive, the first part of the collection has the formal regularity of contemporary postcolonial epics such as Walcott's Omeros. Its narrative trajectory suggests J. P. Clark-Bekederemo's translation of the traditional Ijo epic The Ozidi Saga: an important text for writers of the Niger Delta and a narrative of violence and revenge that provides an important 
poetic and structural framework for authors who wish to examine contemporary conflict. Okpewho has commented on The Ozidi Saga's resonances with postcolonial 'political turmoil' (212), and has pointed to the ways both Clark-Bekederemo's versedrama and Ifowodo's collection use the epic form to convey a 'more than purely local outlook' (221). Yet the magnitude of the environmental and inter-ethnic conflicts described prompt Ifowodo to draw first on the pastoral, then the gothic, and finally on protest-verse and elegy. He divides his book into six initial sections, all of them named after places, from the pre-petroleum waterscape to towns afflicted by blowouts and violence, such as Jese, Odi and Ogoni. This echoes a descent into an oil-fuelled inferno - explicit echoes of Dante occurring in the epigraph and again when the inhabitants of Jese have 'lost all hope' (10). These places are selected as hotbeds of petro-violence: as Egya explains, Ifowodo engages with 'the 1998 fire disaster at Jese, a village in the Niger Delta, which killed hundreds of people scavenging for fuel from burst pipes; and the extra-judicial government order which resulted in wiping out a village called Odi in the Niger Delta whose residents were accused of murdering in cold blood some soldiers in the region' (6). Although LeMenager has rightly stressed the importance of plot to this book, the eventual breakdown of its plot is equally significant. The collection later fragments in its last section 'The Agonist', an elegy for Saro-Wiwa and the Ogoni Eight, as if the epic form has reached breaking point.

Ifowodo, from Edo State in the north-western Delta, begins his collection with the utopian poem 'A Waterscape'. Like Ojaide's utopian poetry of a green lingua franca, he describes what the Delta was like before Shell:

A Waterscape 
Hung above water, hands in the air,

whited tongues and breathing fibrous hair:

roots, white mangrove roots.

Blacker than pear, deeper than soot,

massive ink-well, silent and mute,

water, black water.

Floating hats of lily, yellow plume,

plankton and shrimp, egg-and-fish in bloom,

lakes, ancestral lakes.

Rich mud of eels, water-holes of crab,

sink-place for fisher of dig-and-grab:

bog, mudskippers' bog.

And in the mangrove waters, where tides

free the creeks of weed, fishermen glide

home to the first meal. (xi)

This catalogue of mangroves, shrimps, crabs and mudskippers echoes Saro-Wiwa's lament for these lost edible species of the Delta's creeks, and Ojaide's later reprise of the theme. The formal strategies that Ifowodo uses here are important: a rhyming couplet creates a sense of sonic wholeness, while the final lines ('lakes, ancestral 
lakes') echoes the reassuring repetition of seasonal cycles and fishermen's longestablished routines. By employing rhyme and verbal patterning, Ifowodo makes traditional form evoke traditional practices. His waterscape mentions nothing of deforestation, nor palm oil cultivation, nor the former colonisation of such 'ancestral' lakes by the British - but his use of the pastoral serves to throw his indictments of the oil industry into sharp relief.

The main section of Ifowodo's The Oil Lamp is written in terza rima - both to suggest a Dantesque descent into a hell of gas flares, and to echo the metre of Walcott's Omeros. In this respect, it announces its hybridity and takes its place among postcolonial epics. When Barrett and Worden point to 'the deep cultural entanglement of petroleum and apocalypse' (272), and Frederick Buell links it to the language of catastrophe, they offer productive insights into why Ifowodo chooses Inferno as one of his intertexts. A massive fire at the Jese pipeline occasions the overwrought language of 'the venomous scent of charring bone' and smoke at an 'infernal altar' (11). This recalls Lawrence Buell's insight that '[t]he more toxic discourse focuses on specific cases, the more readily toxic discourse montages into gothic' (1998 653). Pa Piriye, eighteen at the time of the Benin Punitive Expedition, 'revived his tales of $1897^{\prime}$ (24) and wonders 'who shall we curse now, who is the enemy' (31): internecine conflict is framed as 'recolonization'. Major Kitemo, seen as 'chief pacifier $\mid$ of the lower Niger's | still primitive tribes' (37): an allusion to Achebe that sees not the British, but the military, as 'pacifiers' of ethnic minorities.

Satire, irony and protest verse are also important formal strategies that Ifowodo employs. The entire 'Ogoni' section is narrated by Major Kitemo, modelled on Major 
Paul Okuntimo, who was 'notorious for deploying federal troops to commit numerous acts of violence, even massacres of whole villages, in the eastern delta' (Okpewho 224). Kitemo's voice enables Ifowodo to deploy heavy irony: 'I know | two hundred and twenty-one ways to kill a man' (43). The penultimate section of the poem gives voices to victims of inequality in the Delta: 'See where I live - a shack in the swamp! | But light shines on the oil staff estates' (62). It is the direct addresses to the reader that give this section its overtones of protest verse. The series of four poems that ends the collection - three elegies for Saro-Wiwa and 'The Good Pupil', a political attack on a violent leader - swerve from the narrative drive of the main part of the collection and waver between quatrains, couplets and sestets. The plotline breaks down in the aftermath of Saro-Wiwa's death, the poetic form becomes inconsistent, and the narrative concludes on a note of fragmentation and uncertainty.

Okpewho has pointed to Clark-Bekederemo as a role model for younger poets who write of environmental destruction and social disruption (220); his poems such as 'Niger Delta Burning' offer a precedent for them (218). Yet some of ClarkBekederemo's most vivid evocations of the conflicts surrounding foreign resource exploitation are in dramatic form. The medium of live performance allows ClarkBekederemo to create a more vivid sense of the conflicts of the past foreshadowing the problems of the present: rather than reading about them and imagining them, the audience experiences the traditional costumes and songs of the Niger Delta during the early days of colonialism. Another reason why the theatre offers unique formal possibilities is its dependence on dramatic conflict. Conflict is an essential driving force for any plotline, but Clark-Bekederemo's use of it in theatre fuses its primary 
function in Aristotelian tragedy ${ }^{8}$ with its deployment in traditional Ijo performances of epics such as The Ozidi Saga, which the playwright first dramatized in 1966. For Abbott, 'conflict structures narrative;' since Aristotle posited the agon, or 'contest,' as 'the spine of any Greek tragedy'. Narrative conflict provides 'a way for a culture to talk about itself, and possibly resolve, the conflicts that threaten to fracture it' (55). There is no neat resolution to the tension over economic exploitation in ClarkBekederemo's play, although British military oppression is narrowly avoided (ClarkBekederemo 34), and two formerly hostile peoples end up reconciled (66-7). This plotline proposes a possible resolution to the internecine tensions between different peoples of the Niger Delta, but implies that the problems caused by Western interest in the Delta will remain unresolved.

Clark-Bekederemo is by no means the only Niger Delta playwright to engage with resource conflicts between local people and the British. Ola Rotimi's Akassa You Mi, first performed in 1977, focuses on King Koko's attack on the premises of the Royal Niger Company at Akassa in 1895. The Royal Niger Company's primary focus was the palm oil trade. The people of Nembe had become prosperous as 'middlemen between European traders on the coast and the markets in the hinterland' (Green ix). Stringent new trading rules (x) provoked what the British called the 'Akassa Raid'; the people of Nembe 'saw it as a war, to ensure economic survival for their people', terming it the Akassa War or the War Against the White Man (ix). Not only does Rotimi's play provide important parallels with the contemporary economic stranglehold on petroleum resources, but its setting is especially resonant. Nembe is a

\footnotetext{
${ }^{8}$ Clark-Bekederemo illustrates his response to Greek tragedy with the title of his play Song of a Goat (1961): a translation of the Greek word tragoidia, from which tragedy is derived (OED).
} 
current hotbed of 'intra-community violence', with rivals competing to offer 'protection' to oil companies (Watts 2009 20). Yet, while the conflict of Rotimi's play ends with Koko's triumphant victory and a brief warning that 'even our own black brothers' may become the oppressors (134), Clark-Bekederemo closes his play with an alliance between Niger Delta peoples, tempered with a prophetic vision of the oil conflict to come. Clark-Bekederemo also ends his play with a moment of reconciliation, but his play makes more extensive use of prophecies and foreshadowing, as will be examined shortly.

All for Oil takes place in the western Niger Delta in the early 1900s (ClarkBekederemo 1). An introductory passage states that 'Britain declared for itself the Oil Rivers Protectorate to gain monopoly of the palm oil trade', and that 'oil again, this time, petroleum, has been for years the one major commodity making up Nigeria's economy, and indeed the reason for its existence. The players, as in the story before, are the same, namely, the Nigerian State, run by the majority ethnic groups to whom Britain ceded it at independence; the economic partners are the multinational oil companies' (Clark-Bekederemo v). The hero is Chief Bekederemo, the playwright's grandfather (Okpewhe 214). He is an important player in the palm oil trade: 'the largest trader and middleman for the Niger Company in the Western Niger Delta at the beginning of the $20^{\text {th }}$ Century' (vii), operating in a similar role to the middlemen of Ola Rotimi's Nembe. The 'trust' system of palm oil trade was the chief reason for tensions between the British and Niger Delta traders and palm growers at this time:

Tensions were so high because of the business model of the palm oil trade, known as the "trust" system. Under the trust system, British firms on the coast would pay credit to coastal middlemen to procure a specified amount of palm 
oil. The middlemen would use part of this credit to purchase palm oil from hinterland dealers. They would then bring the palm oil back to the British firms in completion of the bargain. The trust system caused increased tensions for many reasons. First, increased competition among Delta and Calabari traders meant that they were in a weakened position vis-à-vis the British firms, which could lower prices by playing them off against each other. Sometimes Delta traders would refuse to trade at low rates, or would look for better rates from different British firms. This angered British traders, particularly from the larger companies, who held the largest amount of middleman debt. Second, the more established British firms could extend so much credit to Delta traders that they could never repay it and, therefore, could not embark on deals with newer British firms, even if these firms were offering better terms. Third, disputes between British creditors and Delta debtors often broke out, with the result that British firms commandeered property from the traders, often in a fashion incommensurate to the outstanding debt. (Falola and Heaton 90) It is against this backdrop of economic tension that the conflict of ClarkBekederemo's play unfolds.

Unlike Rotimi's play, which does not allude to modern-day conflict in the Niger Delta, Clark-Bekederemo's drama is redolent of the language of the petroleum industry. Middleman Bekederemo describes the 'hulks offshore' that are the initial focus of British trade - offshore being a term rich in proleptic resonance. Bekederemo's complaint that their goal is 'plain possession and transfer of our land' certainly applies to the domination of Nigeria as a cluster of protectorates, and then as a full colony; but it smacks of the land acquisition policies of contemporary oil 
companies. Palm oil is described as a 'train', a 'disease', a 'guinea worm' (4) - the language of contemporary technology juxtaposed with the language of disease, which envisages palm oil as a contagion. As the play progresses, images of natural disasters are used of a catalogue of human exploitation and environmental damage:

The Urhobo from Abraka to Olomu; the Isoke from Iyede to Oweh, the Ijaw from Ekeremor to Ayakoroma; the Aboh and Kwale, all have come with their accounts of the damages done to them by this wild elephant that the white man has let loose on us. Accounts of palm oil produce extorted with little or no pay, demands for the best timber for rafters for his house, forced labour to build roads, illegal arrests of men so he can take over their wives, seizure of young girls to breach their virginity for public display, capture of other peoples' livestock to make sacrifices to his gods and ancestors, dispossession of people of their God-given land - oh, what a flash flood now sweeps over our land! (29).

The catalogue of rape, extortion and forced labour is hammered home by ClarkBekederemo's use of catastrophic metaphors. The palm oil industry as a 'wild elephant' and a 'flash flood' are especially significant. These are examples of the language of catastrophe that Frederick Buell sees as an important discourse in writing about mineral oil - not palm oil. In deploying such metaphors, Clark-Bekederemo strengthens his proleptic critique of the oil industry.

At the end of the play, the language of catastrophe and apocalypse returns in a prophecy of Nigeria's future oil economy. Fetaroro, a relative of one of Bekederemo's former enemies, warns Bekederemo that 'a great tornado will come 
upon this land, and then, in spite of all the walls of brick you build around yourself, your life will go out with that oil lamp you have set up to burn for ever there in front of your altar to our Creator' (67). Petroleum envisaged as a 'tornado' employs the catastrophic language characteristic of discourse about oil exploitation, while the snuffing of the lamp on Bekederemo's traditional altar evokes the cultural erosion that comes with (neo-)colonialism. Clark-Bekederemo's use of Fetaroro's prophecy joins Okri's use of prolepsis in lamenting future resource conflicts.

\section{The Flood}

Why does Clark-Bekederemo use images of natural disasters, such as the flood and the tornado, when evoking the all too human consequences of the palm and mineral oil industries? The answer is climate change. According to LeMenager, 'The specter of global climate change [...] accompanies the Tough Oil future' (15). This particular spectre haunts petroleum culture; it manifests in Clark-Bekederemo's play, Okri's fiction, and Ojaide's poetry. As Nixon notes, 'In the mid-90s, when flaring from Nigeria's oil fields was pumping 12 million tons of methane and 35 million tons of carbon dioxide into the atmosphere annually, it was argued by some that this was the single greatest contributor worldwide to climate change' (Nixon 113). Rising sea levels have been known to endanger Nigeria's coastlines since the early 1990s (IPCC). As we have seen, palm oil processing can also contribute to climate change, albeit on a far less dramatic scale. Clark-Bekederemo's play ends with the promise that there will be 'oil for our lamps in the white man's new night market he calls Nigeria' (68). The white man will indeed bring new oil lamps to the night market of his Nigerian commercial ambitions: Clark-Bekederemo's turn of phrase would remind audiences in the Niger Delta of the so-called 'Oil Lamps of the Delta'. Characters in 
Ifowodo's poetry give this nickname to the gas flares from oil refineries that fill their nights with unnatural light (55). What Clark-Bekederemo's early twentieth century characters do not know, but what the audience does know, is that the 'tornado' of freak weather conditions is intrinsically linked to the 'oil lamp' of fossil fuel emissions. In Okri’s eponymous short story 'Stars of the New Curfew', supernatural red rain and a 'terrible flood-tide' (1523) evoke a flood of petrodollars on which a wealthy man surges - but the image also functions to evoke a Niger Delta under increasing threat from rising seas. This trope occurs elsewhere in Okri's fiction: James analyses a passage in Infinite Riches (1998), in which the protagonist is concerned about 'the rising seas and shrinking forests ... [and] the unstable earth and misery to come' (ctd in James 2012 272). In Ojaide's 'desert-advancing land' and Clark-Bekederemo and Okri's flood-prone rivers, climate change is a haunting presence.

In conclusion, the pressures of the oil industry - and in some cases the palm industry - prompt authors of the Niger Delta to reinvent traditional literary forms, confound genre categories, and blur the traditional distinction between human and nonhuman. The downplaying of the Niger Delta's history of palm oil exploitation is an important literary strategy that enables Ojaide, Saro-Wiwa and Ifowodo to highlight the greater scale of devastation brought by petroleum; yet in Okri and Clark-Bekederemo's work, the palm industry is examined at length. These two authors in particular remind their readers of the long history of resource conflict as the Niger Delta transitioned from Slave Coast to Oil Rivers Protectorate, from 'white men's wars' over palm oil to 'recolonization' by ethnic majorities and western oil companies. A changing climate, rising sea levels, and continuing social unrest hint at future problems to come; yet that 
does not diminish the importance of literature as a nonviolent way for authors to be 'engagingly combative' in defence of the Delta. 


\section{$\underline{\text { Works Cited }}$}

Gomba, Obari. 'Niger Delta Dystopia and Environmental Despolation in Tanure Ojaide's Poetry.' Eco-Critical Literature: Regreening African Landscapes. Ed. Ogaga Okuyade. Lagos, NGA: African Heritage Press, 2013. Pp. 239-58. Print.

Aghalino, S. O. 'British colonial policies and the oil palm industry in the Niger delta region of Nigeria, 1900-1960'. African Study Monographs 21.1 (January 2000): 19-33. Print.

Ayodele, Thompson and Eshalomi, Matthew. 'Africa Case Study: Palm Oil and Economic Development in Nigeria; Recommendations for the World Bank's 2010 Palm Oil Strategy'. Lagos: Initiative for Public Policy Analysis and World Bank, 2010. Print.

Barrett, Ross and Daniel Worden. 'Oil Culture: Guest Editors' Introduction.' Journal of American Studies 46.2 (May 2012): 269-72.

Berger, K. G. and Susan Martin. 'Palm Oil'. The Cambridge World History of Food. Eds Kenneth Kiple and Kriemhild Coneè Ornelas. Vol. 2. Cambridge: Cambridge UP 2000. Pp. 397-410. Print.

Beinart, William. 'African History and Environmental History.' African Affairs 99 (2000): 269-302. Print. 
Benito, Jesús, Ana M. Manzanas and Begoña Simal. Uncertain Mirrors: Magical Realisms in US Ethnic Literatures. Amsterdam: Rodopi, 2009. Print.

Bodunde, Charles. 'Tanure Ojaide's Poetry and the Delta Landscape: A Study of Delta Blues and Home Songs.' Writing the Homeland: The Poetry and Politics of Tanure Ojaide. Ed. Onookome Okome. Bayreuth: Bayreuth African Studies, 2002. Pp. 195-208. Print.

Brooks, Cleanth. Modern Rhetoric. New York: Harcourt, 1979. Print.

Buell, Frederick. 'A Short History of Oil Cultures: or, The Marriage of Catastrophe and exuberance.' Oil Culture. Eds Ross Barrett and Daniel Worden. Minneapolis: Minnesota UP, 2014. Print.

Buell, Lawrence. The Environmental Imagination: Thoreau, Nature Writing, and the Formation of American Culture. Cambridge MA: Harvard Belknap, 1995. Print.

---. 'Toxic Discourse'. Critical Inquiry 24.3 (Spring 1998): 639-665. Print.

Caminero-Santangelo, Byron. African Fiction and Joseph Conrad: Reading Postcolonial Intertextuality. New York: State of New York UP, 2004. Print.

---. Different Shades of Green: African Literature, Environmental Justice, and Political Ecology. Charlottesville: Virginia UP, 2014. Print. 
Carson, Rachel. Silent Spring. London: Penguin, 2000. Print.

Chakrabarty, Dipesh. 'The Climate of History: Four Theses.' Critical Inquiry 35.2 (Winter 2009): 197-222. Print.

Clark, J. P. [Clark-Bekederemo]. All for Oil. Ikeja: Malthouse, 2000. Print.

Clark, Timothy. Ecocriticism on the Edge: The Anthropocene as a Threshold Concept. London: Bloomsbury, 2015. Print.

Doron, Roy, and Toyin Falola. Ken Saro-Wiwa. Ohio: Ohio UP, 2016. Kindle.

Egya, Sule Emmanuel. 'Nature and environmentalism of the poor: eco-poetry from the Niger Delta region of Nigeria.' Journal of African Cultural Studies 28.1 (2016): 1-12. Print.

Falola, Toyin and Adam Paddock, eds. Environment and Economics in Nigeria. Abingdon: Routledge 2011. Print.

---, and Matthew Heaton. A History of Nigeria. Cambridge: Cambridge UP, 2008. Print.

Gifford, Terry. 'Pastoral, Anti-Pastoral and Post-Pastoral as Reading Strategies'. Critical Insights: Nature and Environment. Ed. Scott Slovic. Ipswich: Salam, 2012. Pp. 42-61. Print. 
Gilcrest, David. Greening the Lyre: Environmental Poetics and Ethics. Reno: Nevada UP, 2002. Print.

Green, Eldred Ibibiem. 'Introduction'. Ola Rotimi. Akassa You Mi. Port Harcourt: Port Harcourt UP, 2001. Print. Pp. Ix-Xv.

Havinden, Michael, and Meredith, David. Colonialism and Development: Britain and Its Tropical Colonies, 1850-1960. London: Routledge, 1993. Print.

Hosseini, Seyed Ehsan, and Maslan Abdul Wahid. 'Pollutant in palm oil production process.' Journal of the Air \& Waste Management Association 65.7 (2013): 773-81. Print.

Ifowodo, Ogaga. The Oil Lamp. Asmara: Africa World Press, 2005. Print.

Intergovernmental Panel on Climate Change. 'The regional impacts of climate change: Nigeria'. 2014. Web. $3^{\text {rd }}$ Feb 2016. http://www.ipcc.ch/ipccreports/sres/regional/index.php?idp=31

James, Erin. 'Bioregionalism, Postcolonial Literatures, and Ben Okri's The Famished Road'. Eds Tom Lynch, Cheryll Glotfelty, and Karla Armbruster. The Bioregional Imagination: Literature, Ecology and Place. Athens, GA: University of Georgia Press, 2012. Pp. 263-77. Print.

---. The Storyworld Accord: Econarratology and Postcolonial Narratives. Lincoln: Nebraska UP, 2015. Print. 
Knickerbocker, Scott. Ecopoetics: The Language of Nature, The Nature of Language. Amherst: Massachusetts UP, 2012. Print.

Kpone-Tonwe, S. and J. Salmons. 'The Arts of the Ogoni'. Ways of the Rivers: Arts and Environment of the Niger Delta. Eds M.G. Anderson and P.M. Peek. Los Angeles: UCLA, 2002. Pp. 275-301. Print.

Lanham, Richard. A Handlist of Rhetorical Terms. Berkeley: California UP, 1991. Print.

Lynn, Martin. 'The West African palm oil trade in the nineteenth century and the 'crisis of adaptation'. From Slave Trade to 'Legitimate' Commerce: The commercial transition in nineteenth-century West Africa. Ed. Robin Law. Cambridge: Cambridge University Press, 1995. Pp. 57-77. Print.

Maddox, Gregory. Sub-Saharan Africa: An Environmental History. Santa Barbara: ABC-CLIO, 2006. Print.

Mandela, Nelson. 'I am prepared to die'. Audio transcript of speech. $20^{\text {th }}$ April 1964. Web. 30 $0^{\text {th }}$ March 2017.

http://db.nelsonmandela.org/speeches/pub_view.asp?pg=item\&ItemID=NMS01 0\&txtstr=prepared $\% 20$ to $\% 20$ die

Martin, Susan M. Palm Oil and Protest: An Economic History of the Ngwa Region, South-Eastern Nigeria, 1800-1980. Cambridge: Cambridge UP, 1988. Print. 
---. 'Slaves, Igbo women and palm oil in the nineteenth-century'. From Slave Trade to 'Legitimate Commerce': the commercial transition in nineteenth-century West Africa. Ed. Robin Law. Cambridge: Cambridge UP 1995. 172-194. Print.

Matera, Mark, Misty Bastian and Susan Kingsley Kent. The Women's War of 1929: Gender and Violence in Colonial Nigeria. Basingstoke: Palgrave Macmillan, 2012. Print.

Morton, Timothy. 'The Dark Ecology of Elegy'. The Oxford Handbook of the Elegy. Ed. Karen Weisman. Oxford: Oxford UP, 2010. Pp. 251-71. Print.

Ojaide, Tanure. Labyrinths of the Delta. New York: Greenfield Review Press, 1986. Print.

---. 'I Want to Be an Oracle: My Poetry and My Generation.' World Literature Today 68.1 (winter 1994): 15-21. Print.

---. Delta Blues and Home Songs. Ibadan: Kraft Ibadan UP, 1997. Print.

Okpewho, Isidore. Blood on the Tides: The Ozidi Saga and Oral Epic Narratology. Rochester, NY: Rochester UP, 2014. Print.

Okuyade, Ogaga. 2013. 'Introduction: African Cultural Art Forms, Eco-activism, and (Eco)-logical Consciousness.' Eco-critical Literature: Regreening African Landscapes. Ed. Ogaga Okuyade. New York: African Heritage Press, 2013. Pp. ix-Xviii. Print. 
Osodi, George. Delta Nigeria: The Rape of Paradise. London: Trolley, 2011. Print.

Ramazani, Jahan. Poetry of Mourning: The Modern Elegy from Hardy to Heaney. Chicago: Chicago UP, 1994. Print.

Rome, Adam. " "Give Earth a Chance": The Environmental Movement and The Sixties'. The Journal of American History 90.2 (2003): 524-54. Print.

Rotimi, Ola. Akassa You Mi. Port Harcourt: Port Harcourt UP, 2001. Print.

Saro-Wiwa, Ken. Nigeria: The Brink of Disaster. Port Harcourt: Saros International, 1991. Print.

---. Genocide in Nigeria: The Ogoni Tragedy. Port Harcourt: Saros, 1992. Print.

---. A Month and a Day: A Detention Diary. London: Penguin, 1995.

Saro-Wiwa, Noo. Looking for Transwonderland: Travels in Nigeria. London: Granta, 2012.

Stoekl, Allan. 'Foreword'. Oil Culture. Eds Ross Barrett and Daniel Worden. Minneapolis: Minnesota UP, 2014. Kindle. Locs 88-53.

Szeman, Imre. 'System Failure: Oil, Futurity and the Anticipation of Disaster.' South Atlantic Quarterly 106.4 (Fall 2007): 805-23. Print. 
Tutuola, Amos. The Palm-Wine Drinkard, and his Dead Palm-Wine Tapster in the Deads'Town. London: Faber \& Faber 1952. Kindle.

United Nations Food and Agriculture Programme, Africa regional office. 'Oil exploitation, fisheries resources and sustainable livelihood in the Niger delta, Nigeria'. Nature \& Faune 24.1 (December 2009): 56-88. Print.

United Nations Environmental Programme. 'Environmental Assessment of Ogoniland'. Nairobi: United Nations Environment Programme, 2011. Print.

Walcott, Derek. Omeros. London: Faber \& Faber, 1990. Print.

Warnes, Chris. Magical Realism and the Postcolonial Novel: Between Faith and Irreverence. Basingstoke: Palgrave Macmillan, 2009. Print.

Watts, Michael. Petro-Violence: 'Community, Extraction and Political Ecology of a Mythic Commodity.' Violent Environments. Eds Michael Watts and Nancy Lee Peluso. Ithaca: Cornell UP, 2001. Pp. 189-212. Print.

---. 'Crude Politics: Life and Death on the Nigerian Oil Fields.' Niger Delta Economies of Violence Working Papers. 2009. Print.

World Bank Group. 'The World Bank Group Framework and IFC Strategy for Engagement in the Palm Oil Sector.' Washington DC: World Bank Group and International Finance Corporation, 2011. Print. 
